\title{
Duchenne's Muscular Dystrophy and the Xg Blood Groups: a Search for Linkage
}

\author{
HELEN BLYTH, C. O. CARTER, V. DUBOWITZ, A. E. H. EMERY, JUNE GAVIN, \\ H. A. JOHNSTON, V. A. McKUSICK, R. R. RACE, RUTH SANGER, \\ and PATRICIA TIPPETT
}

From University of Leeds; M.R.C. Clinical Genetics Research Unit, Institute of Child Health, The Hospital for Sick Children, London; Department of Child Health, University of Sheffield; Division of Medical Genetics, Department of Medicine, University of Manchester; M.R.C. Blood Group Research Unit, The Lister Institute, London; M.R.C. Population Genetics Research Unit, Oxford; and The Moore Clinic, The fohns Hopkins Hospital, Baltimore, U.S.A.

Clark, Puite, Marczynski, and Mann (1962) determined the $\mathrm{Xg}$ groups of a series of families with Duchenne's muscular dystrophy, living in the State of Michigan and in the northern part of Indiana. The results showed that the loci for the two genes involved were not close to each other on the $\mathbf{X}$ chromosome. Details of the families and the linkage calculations were given in a later paper by the same authors (1963). The present paper contributes more information and supports these earlier results.

For linkage studies it is important to ensure as far as is possible that each group of families considered is genetically homogeneous. Clinical differences may be assumed to represent genetic differences provided that all affected members of a given family belong to one and the same clinical group. Becker (1955) and Becker and Kiener (1955) noted that the typical $\mathrm{X}$-linked recessive pattern of inheritance might be associated with a relatively benign form of Duchenne type muscular dystrophy, as well as with the more usual severe form with its early onset, rapid progression, and death at the beginning of the third decade at the latest. Becker's conclusion that two different mutations might be concerned is now generally shared. He suggested further that the two mutant genes might be alleles, but there is no evidence yet either for or against this view.

To facilitate clinical grouping, families with the severe form of the disease may be distinguished by the criterion suggested by Stevenson (1953) and Blyth and Pugh (1959) that all patients are, or are expected to be, unable to walk unsupported by the age of I I years. Families with the milder type of disability may similarly be distinguished as those in which all patients are, or are expected

Received March 16, 1965. to be, able to walk unsupported at the age of I I years. In the opinion of some of the present authors this age could be advanced by a year or two. The division of cases into severe and mild to be used in the linkage analysis is that made by the individual authors.

\section{Informative Data}

The red cells of 335 members of 50 kindred with X-linked Duchenne's muscular dystrophy were tested with anti-Xga. In 12 kindred, I4 mothers showed themselves to be heterozygous both for the Duchenne and the Xg genes. Some details of these informative families are given in Table I. Two families present the mild form of the dystrophy and ro the severe.

\section{Linkage Analysis}

The data were analysed by the application of the lod scores of Morton (1955) as instructed by Maynard-Smith, Penrose, and Smith (I96I). The lod scores are given in Table II together with the anti-logs of their sums. These antilogs represent the relative probabilities of $\theta$, the recombination fraction, and they are plotted in the Figure.

The curve for the severe form of the dystrophy shows that $\mathrm{Xg}$ and the gene responsible for this form are probably not within measurable distance of each other. The lower limit of $\theta$ at the $I$ in 20 level of probability is about 0.35 , a figure obtained by the method recommended by Professor C. A. B. Smith, of counting the graph paper squares below the curve and cutting off from the tail one-twentieth of their number.

The question of a priori corrections in X-linkage calculations was raised by Dr. J. H. Renwick (Davies, Gavin, Goldsmith, Graham, Hamper, Hardisty, Harris, Holman, Ingram, Jones, McAfee, McKusick, O'Brien, Race, Sanger, and Tippett, 
TABLE I

DUCHENNE'S MUSCULAR DYSTROPHY AND Xg GROUPS: FAMILIES GIVING LINKAGE INFORMATION

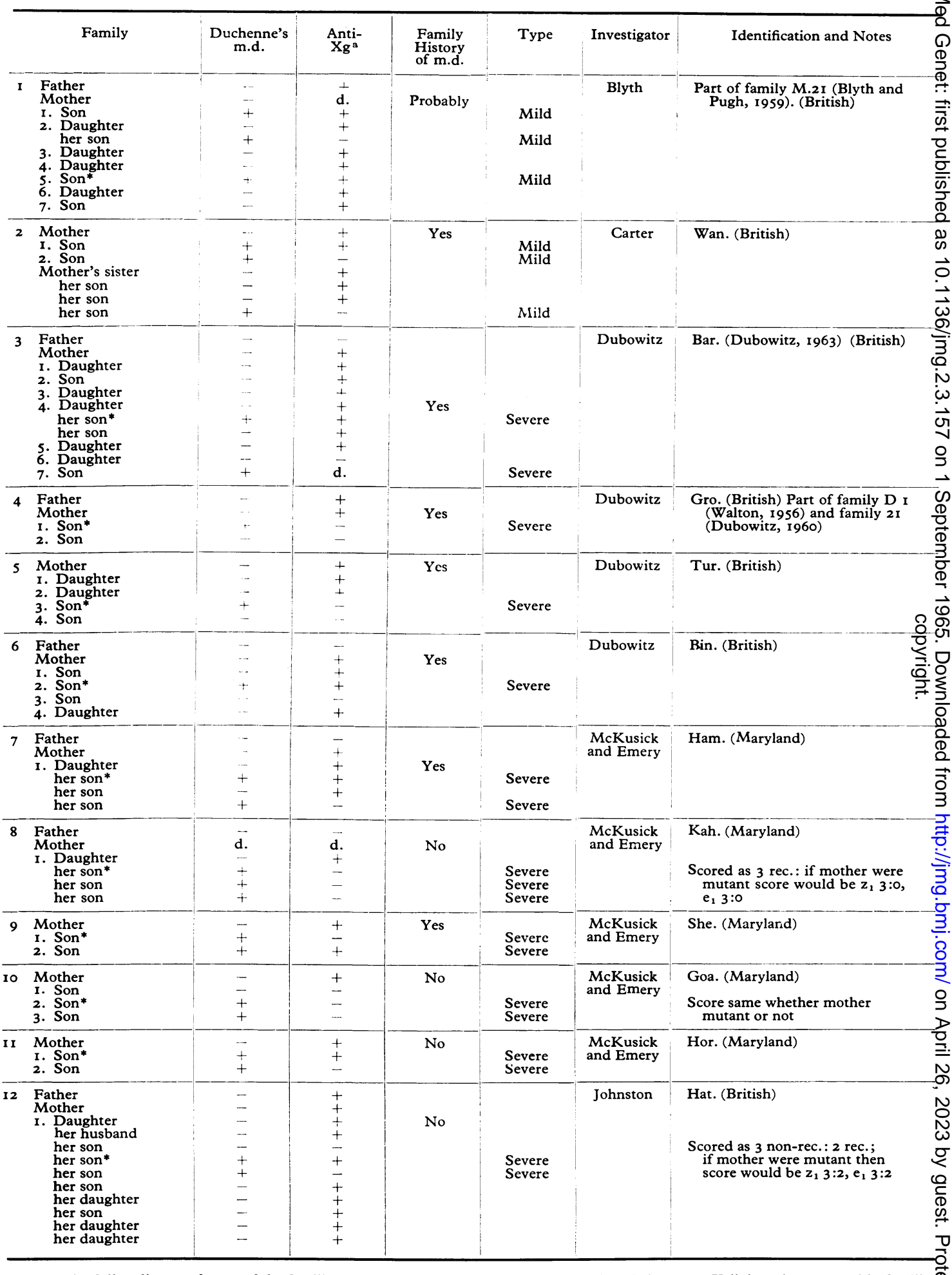

Note: The full pedigrees of most of the families showed the pattern expected of an X-linked character: X-linkage is presumed in families, 8, 10, I I, and 12. In the column headed 'Family history of m.d.' 'Yes' opposite a member's name means that other cases are known in earlier generations or in sibs and that the person so indicated cannot therefore represent a fresh mutation: 'No' means that the person could repre- $\triangle$ sent a fresh mutation.

* The propositus is marked with an asterisk when present in the part of a family shown in this Table. 
TABLE II

DUCHENNE'S MUSCULAR DYSTROPHY AND Xg: LOD SCORES OF FAMILIES IN TABLE I

\begin{tabular}{|c|c|c|c|c|c|c|c|c|c|c|c|}
\hline \multirow[b]{3}{*}{$\begin{array}{c}\text { Mild type } \\
\text { Family }\end{array}$} & \multirow[b]{3}{*}{$\begin{array}{c}\mathrm{I}(\mathrm{M.2I}) \\
,\end{array}$} & \multirow[b]{3}{*}{$\begin{array}{l}z_{1} 2: 2, e_{1} 3: 1 \\
\text { I n-rec. }\end{array}$} & \multicolumn{9}{|c|}{ Recombination Fraction, $\theta$} \\
\hline & & & 0.05 & 0.1 & 0.15 & 0.2 & 0.25 & 0.3 & 0.35 & 0.4 & 0.45 \\
\hline & & & $\begin{array}{r}-I \cdot 46 I \\
0.279\end{array}$ & $\begin{array}{r}-0.899 \\
0.255\end{array}$ & $\begin{array}{r}-0.592 \\
0.230\end{array}$ & $\begin{array}{r}-0.392 \\
0.204\end{array}$ & $\begin{array}{r}-0.252 \\
0.176\end{array}$ & $\begin{array}{r}-0.152 \\
0.146\end{array}$ & $\begin{array}{r}-0.082 \\
0.114\end{array}$ & $\begin{array}{r}-0.035 \\
0.079\end{array}$ & $\begin{array}{r}-0.009 \\
0.041\end{array}$ \\
\hline ", & 2 (Wan.) & $\begin{array}{l}z_{1}:: 1, e_{1} 2: 0 \\
z_{1} 3: 0, e_{1} 2: 1\end{array}$ & $\begin{array}{r}-0.584 \\
0.485\end{array}$ & $\begin{array}{r}-0.340 \\
0.427\end{array}$ & $\begin{array}{r}-0.215 \\
0.364\end{array}$ & $\begin{array}{r}-0.138 \\
0.296\end{array}$ & $\begin{array}{r}-0.087 \\
0.228\end{array}$ & $\begin{array}{r}-0.052 \\
0.160\end{array}$ & $\begin{array}{r}-0.028 \\
0.098\end{array}$ & $\begin{array}{r}-0.012 \\
0.047\end{array}$ & $\begin{array}{r}-0.003 \\
0.012\end{array}$ \\
\hline \multicolumn{3}{|c|}{$\begin{array}{l}\text { Sum of lod scores } \\
\text { Antilog }=\text { relative probabilities of } \theta\end{array}$} & $\begin{array}{r}-I \cdot 28 I \\
0.052\end{array}$ & $\begin{array}{r}-0.557 \\
0.277\end{array}$ & $\begin{array}{r}-0.213 \\
0.612\end{array}$ & $\begin{array}{r}-0.030 \\
0.933\end{array}$ & $\begin{array}{l}0.065 \\
I \cdot 161\end{array}$ & $\begin{array}{l}0 \cdot 102 \\
1 \cdot 265\end{array}$ & $\begin{array}{l}0 \cdot 102 \\
1 \cdot 265\end{array}$ & $\begin{array}{l}0.079 \\
I \cdot 199\end{array}$ & $\begin{array}{l}0.041 \\
1 \cdot 099\end{array}$ \\
\hline \multirow[t]{4}{*}{$\begin{array}{c}\text { Severe type } \\
\text { Family }\end{array}$} & 3 (Bar.) & $\begin{array}{l}z_{1} I: I \\
\text { I n-rec.: I rec. }\end{array}$ & $\begin{array}{l}-0.721 \\
-0.721\end{array}$ & $\begin{array}{l}-0.444 \\
-0.444\end{array}$ & $\begin{array}{l}-0.292 \\
-0.293\end{array}$ & $\begin{array}{l}-0.194 \\
-0.194\end{array}$ & $\begin{array}{l}-0.125 \\
-0.125\end{array}$ & $\begin{array}{l}-0.076 \\
-0.076\end{array}$ & $\begin{array}{l}-0.041 \\
-0.041\end{array}$ & $\begin{array}{l}-0.018 \\
-0.018\end{array}$ & $\begin{array}{l}-0.004 \\
-0.005\end{array}$ \\
\hline & 4 (Gro.) & $z_{1} \mathbf{I}: \mathbf{r}, \mathbf{e}_{1} \mathbf{I}: \mathbf{I}$ & -0.825 & -0.528 & -0.358 & -0.243 & -0.160 & -0.099 & -0.054 & -0.024 & -0.005 \\
\hline & 5 (Tur.) & $\mathrm{z}_{1} \mathrm{I}: \mathrm{I}, \mathrm{e}_{1} \mathrm{I}: \mathrm{I}$ & -0.825 & -0.528 & -0.358 & -0.243 & -0.160 & -0.099 & -0.054 & -0.024 & -0.005 \\
\hline & 6 (Bin.) & $\mathrm{z}_{1} 2: \mathrm{I}, \mathrm{e}_{1} 2: \mathrm{I}$ & -0.769 & -0.482 & -0.321 & -0.216 & -0.140 & -0.086 & -0.047 & -0.020 & -0.005 \\
\hline ", & 7 (Ham.) & I n-rec. : 2 rec. & $-1 \cdot 72 I$ & $-I \cdot I 43$ & -0.816 & -0.592 & -0.426 & -0.298 & -0.196 & -0.115 & -0.051 \\
\hline ", & 8 (Kah.) & $: 3 \mathrm{rec}$ & $-3 \cdot 000$ & $-2 \cdot 097$ & $-I \cdot 569$ & $-I \cdot 194$ & -0.903 & -0.666 & -0.465 & $-0.29 I$ & -0.138 \\
\hline ", & 9 (She.) & $z_{1} I: I, e_{1} 2: 0$ & -0.584 & -0.340 & -0.215 & -0.138 & -0.087 & -0.052 & -0.028 & -0.012 & -0.003 \\
\hline ", & Io (Goa.) & $z_{1} 2: I, e_{1} 2: I$ & -0.769 & -0.482 & -0.321 & -0.216 & -0.140 & -0.086 & -0.047 & -0.020 & -0.005 \\
\hline , & I I (Hor.) & $z_{1} I: I, e_{1} 2: 0$ & -0.584 & -0.340 & -0.215 & -0.138 & -0.087 & -0.052 & -0.028 & -0.012 & -0.003 \\
\hline " & 12 (Hat.) & 3 n-rec. : 2 rec. & $-I \cdot 163$ & -0.633 & -0.356 & -0.184 & -0.074 & -0.006 & 0.032 & 0.043 & 0.031 \\
\hline \multicolumn{3}{|c|}{ Sum of lod scores } & $-11 \cdot 682$ & $-7 \cdot 461$ & $-5 \cdot 114$ & $-3 \cdot 552$ & $-2 \cdot 427$ & $-I \cdot 596$ & -0.969 & -0.511 & -0.193 \\
\hline \multicolumn{3}{|c|}{ Antilog $=$ relative probabilities of $\theta$} & 0.000 & 0.000 & 0.000 & 0.000 & 0.004 & 0.025 & $0 \cdot 107$ & 0.308 & 0.641 \\
\hline
\end{tabular}

FIG. The linkage relations of the genes for Duchenne's muscular dystrophy and for the Xg blood groups: the left curve relates the mild form of the dystrophy, the right curve the severe.

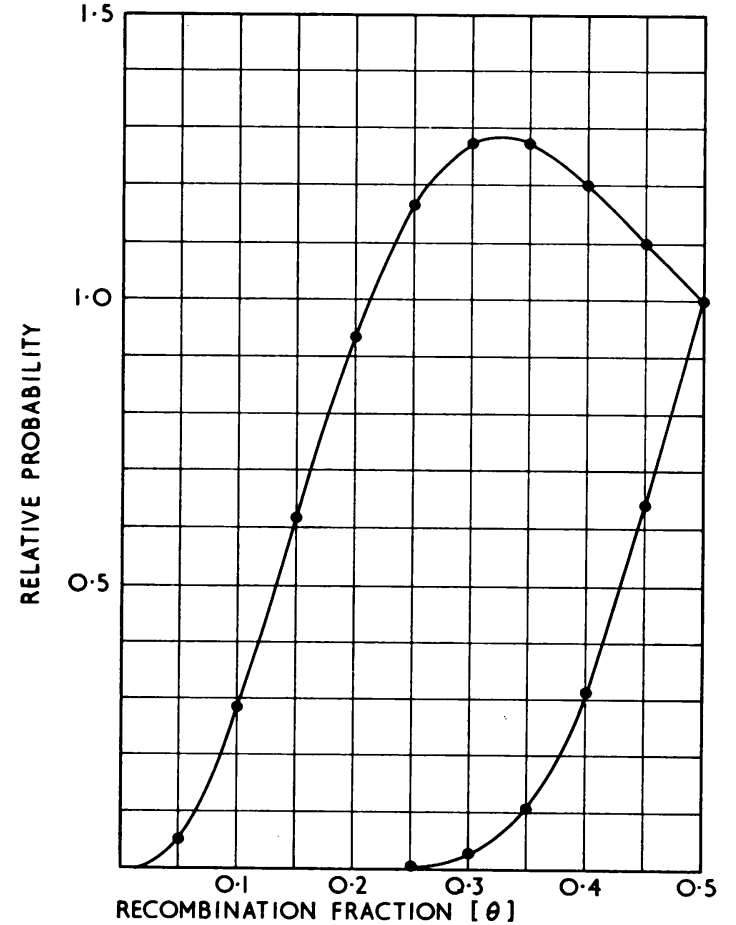


1963; Clark et al., 1963). No correction has been applied to the data in Table II or in the Figure. A correction can be applied later when more is known about the length of the $X$.

From the description it seems likely that the families studied by Clark et al. (1963) were all of the severe type. If the lod scores (uncorrected) of these families are added to those of Table II then the resulting antilog curve moves a little to the right of that in the Figure and the lower limit of $\theta$ at the $I$ in 20 level of probability is increased from 0.35 to 0.38 .

The curve for the mild form of the dystrophy (Fig.) is much too low to be significant of measurable linkage with $\mathrm{Xg}$ : it is, however, an indication that more families with the mild form should be grouped. If the gene for the mild form were found to be within measurable distance of $\mathrm{Xg}$, this would be of interest in showing that the mild and severe forms are not controlled by allelic genes.

\section{Summary}

Members of 50 kindred in which X-linked Duchenne's muscular dystrophy occurs were tested for the $\mathrm{Xg}$ blood groups. Twelve of the kindred provided useful linkage information: two of them showed the mild form of the dystrophy and ten the severe. Analysis by the lod score method gives no hint of measurable linkage between the genes for $\mathrm{Xg}$ and the severe form of dystrophy, and this supports the previous results of Clark, Puite, Marczynski, and Mann. Nothing can yet be said about the linkage relation of $\mathrm{Xg}$ and the mild form of dystrophy: more families will have to be tested.

First we thank the patients and their relatives for their collaboration. We also thank the following who sent samples of blood from seven of the families not included in this report because the $\mathrm{Xg}$ groups did not segregate informatively: Dr. A. Adam, Government Hospitâ, Tel-Hashomer, Israel; Dr. J. van den Bosch, T Galton Laboratory, University College, Londoñ; Dr. M. Espir, The Leicester Royal Infirmary, Leicestef; Dr. P. Ferrier, Clinique Universitaire de Pédiatrié, Hôpital Cantonal, Geneva; Dr. J. Maguire, Armagh County Health Committee, Northern Ireland. Dr. F. Dunsford, National Blood Transfusion Servigg, Sheffield, helped in making arrangements for t tye collection of some of the samples. Dr. D. Lawsen kindly allowed one of the authors access to patients previously studied at Queen Mary's Hospital, Cấshalton. Mr. R. Bolton, Leeds Regional Transfusie Laboratory, gave valuable technical help.

Once again we thank Dr. A. Cahan, Knickerbock Biologics, New York, and Dr. J. D. Mann, Butterworo⿰⿺乚一匕 Hospital, Grand Rapids for supplies of the anti-X plasma.

Becker, P. E. (1955). Zur Genetik der Myopathien. Dtsch.

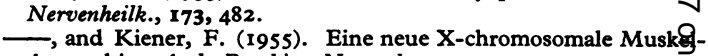
dystrophie. Arch. Psychiat. Nervenkr., 193, 427.

Blyth, H., and Pugh, R. J. (I959). Musculat dystrophy in childhoog. The genetic aspect. Ann. hum. Genet., 23, 127.

Clark, J., Puite, R. H., Marczynski, R., and Mann, J. D. (1968). Duchenne muscular dystrophy and the $\mathrm{Xg}$ blood-groups. Lanagt, I, 1026.

$\longrightarrow,-\longrightarrow$, and - (1963). Evidence for the absence detectable linkage between the genes for Duchenne muscuir dystrophy and the Xg blood group. Amer. F. hum. Genet., 15, 292.

Davies, S. H., Gavin, J., Goldsmith, K. L. G., Graham, $\mathcal{B}$ : Hamper, J., Hardisty, R. M., Harris, J. B., Holman, $\mathbb{E}$. Ingram, G. I. C., Jones, T. G., McAfee, L. A., McKusick, A., O'Brien, J. R., Race, R. R., Sanger, R., and Tippett, P. (19.6). mas disease) to the $\mathrm{Xg}$ blood group system. ibid., 15, 481.

Dubowitz, V. (1960). Progressive Muscular Dystrophy in Chi hood. M.D. Thesis, University of Capteown.

(1963). Myopathic changes in a muscular dystrophy carrif f. Neurol. Neurosurg. Psychiat., 26, 322.

Maynard-Smith, S., Penrose, L. S., and Smith, C. A. B. (196) Mathematical Tables for Research Workers in Human Genetig. Churchill, London. Morton, N. E. (1955). Sequential tests for the detection of linkage.
Amer. F. hum. Genet., 7, 277 .

Stevenson, A. C. (1953). Muscular dystrophy in Northern Irelange I. An account of the condition in fifty-one families. Ann. Eugen. (Lond.), 18, 50 .

Walton, J. N. (1956). The inheritance of muscular dystroph: further observations. Ann. hum. Genet., 21, 40. 